\title{
Story of a counter monument: Doris Salcedo's Fragmentos in Bogotá
}

\section{Patrizia Violi}

This paper aims to discuss the controversial notion of 'counter monument', often used in different ways not always consistent with each other. In order to overcome this difficulty, counter monumentalization is defined as a practice that can assume various forms. The first part of the paper identifies two types of counter monuments. The second part analyses Fragmentos by Doris Salcedo, a counter monument recently realized in Bogota, to remember the terrible and long-lasting war in Colombia.

\section{Keywords Counter monuments, re-semantization, memory, Colombia,} Doris Salcedo

\section{Two types of counter monuments}

Since the seminal paper by James Young (1992), the category of counter monuments has been used in different ways not always consistent with each other. The category is yet not clearly defined and can refer to quite different artifacts and practices. The prefix counteralludes to a polemic dimension and an opposition to other monumental forms, but it is not always clear to what a counter monument is opposed. I suggest there are two types of counter monuments (Violi 2019).

The first is a practice rather than a monumental artefact. It consists in the re-semantization of an already existing monument which carries a bygone value system currently perceived as unacceptable by the community to which it belongs. This is the case of the difficult heritage (Macdonald 2009) of Nazism in Germany, Fascism in Italy, Francoism in Spain and more recently of Communism in the former Soviet Union. In these cases, monuments erected during the regime represent values that not only are not shared by the community anymore but are also perceived as controversial and potentially dangerous. Two are the options to neutralize 
their past meaning: destruction of the monument or the re-semantization of its meanings which can assume many different forms: for example, monuments in prominent locations can be relocated in less relevant areas of the city, as it happened in Budapest with the statues erected during the Socialist period; otherwise, monuments can be used in ways that are different from the original, as analyzed by Mario Panico (2018) in relation to the Monument to the Red Army in the city center of Sofia.

The second type of counter-monumentalization refers to newly erected monuments opposing the classical, traditional rhetoric of monumentalization. This is the case, for example, of most of the memorials for the victims of the Shoah all over in Europe and especially in Germany. After the Second World War, it was felt impossible to reproduce the classical monumental style that was used to celebrate traditional figures such as kings and generals, saints and poets. A completely new style was necessary to remember the unthinkable tragedy of the Jewish Holocaust. Therefore, different forms of counter-monuments were created to radically oppose the rhetoric of monuments and memorials used until the Second World War.

Classical monuments generally present realistic representations and are made to be seen and to last in time and. Thus, three seem to be the main features of classical monuments: i. figurative forms, ii. visibility, iii. durability in time. These are the features that are deconstructed in newly erected counter monuments. First counter monuments often present non-realistic representations affecting their forms and dimensions, as for example in the Stolpersteine (in English stumbling block) by the German artist Gunter Demnig. Second, they call into question the durability (and therefore the visibility) of their forms. Many counter-monuments are monuments made not to last forever, monuments that will disappear with time going on. They are only temporary artefacts symbolizing the vanishing of memory itself: for example, the Monument Against Fascism, War, and Violence-and for Peace and Human Rights by Jochen Gerz and Esther Shalev-Gerz, that stood in Hamburg, Germany from 1986 to 1993; the sunken Aschrottbrunnen fountain by Horst Hoheisel in Kessel, Germany (1985). More recently an extraordinary example of a work that will disappear in due time is the vast and fading frieze Triumphs \& Laments by William Kentridge along the river Tiber in Rome.

Notably, the two types of counter monuments here described are not exhaustive: the kinds and styles of counter monumentalization practices can be many and they do not prefigurate an established and pre-fixed format.

\section{An analysis of Fragmentos by Doris Salcedo}

This section analyses a very interesting and particular form of counter-monument: Fragmentos, a walking-through installation by the Colombian artist Doris Salcedo. It was erected in December 2019 in Bogotá, Colombia. The installation can in full right be considered as a 
counter monument: the artist herself defined it as such. Before analysis, a brief historical context is needed.

\section{The historical context of the Colombian civil war}

The history of Colombia from the mid-20 $0^{\text {th }}$ century to today today has been characterized by violence and terror and it is one of the most tragic and dramatic of the whole Latin American continent. The starting point of violence is considered to be the assassination of Jorge Eliécer Gaitán on 9 April 1948. Gaitán was the candidate of the Liberal Party to the 1950 national elections. He was enormously popular for his democratic and social positions as well as for his radical opposition to the corrupted government in charge. After his assassination, the so-called Bogotazo broke out in Bogotá, many days of rioting during which some 3,000 people were killed. (Alape 1983; Gonzalo Sánchez 1983).

Since then, a civil war named La Violencia was fought by many different actors supporting different forces. Starting from the mid-60's, various revolutionary and guerrilla movements such as the FARC (Fuerzas Armadas Revolucionarias de Colombia) and the ELN (Ejército de Liberación Nacional) started an armed struggle against the government and the regular military forces. Two other actors had major role in this conflict: the narco-terrorists and the paramilitary organizations of the extreme right, allied with the regular military force, that were responsible for the $80 \%$ of the people killed over the five decades of civil war.

Since 2012 various attempts to reach a peace agreement have been done. After long and complex negotiations, on 24 November 2016 the President Juan Manuel Santos signed with FARC a peace agreement according to which FARC's guerrilla groups should surrender their weapons to the United Nations (UN).

\section{Commemorating the Colombian conflict: Towards Fragmentos}

One article of the 2016 peace agreement stated that, as mandatory part of the agreement itself, three monuments will be realized to commemorate the achieved peace: the first in Bogotá, the second at the headquarters of the UN in New York, and a third one in Havana where the negotiation meetings took place.

Notably, the pace agreement stated that the monument in Bogota had to be constructed using the weapons surrendered by the over 13,000 members of FARC forces: 8994 weapons were surrendered to the UN and later used as materials to build the Doris Salcedo's monument, as an information plaque at its site explains. At the moment of writing, only the Bogotá monument was realized. The one in New York is still a work in progress and there is no precise news about the monument in Havana.

Doris Salcedo, the world-famous Colombian artist, won the competition for the realization 
of the Bogotá monument in October 2019. The artist set two conditions for its construction: first, the monument should not be a monument dedicated to peace but to the victims of the conflict: she explicitly referred to is as a counter monument for victims and not for peace; second, the monument should be located in the city center of Bogotá.

Both these conditions are highly relevant: refusing the common rhetoric of peace, Salcedo wanted to dedicate her work to the victims and especially - as we will see - to women victims. Despite the 2016 peace agreement, Colombia is still far from being a pacified country, while thousands of victims still remain without compensation or recognition. The location also has a precise function: Barrio Santa Barbara, in Bogotá's old colonial downtown, about one kilometer from Bolivar Square - the main square of the city surrounded by historical buildings such as the Palace of Justice and the National Capitol. This central location underlines the relevance that the victims should deserve in today's Colombian public life, while reasserting the centrality of the recent tragic events of the Colombian civil war.

\section{Turning ruins into a counter monument}

The only free location in the area was a small, dismissed site with abandoned ruins of an old colonial house form the $16^{\text {th }}$ Century. In the 50's, the house was owned by Secundino Navarro, a wealthy man who died in 1962 without leaving heirs. The house thus became propriety of the Colombian state, that however did not use it for any specific purpose. Without proper maintenance, the whole building slowly deteriorated and eventually collapsed, creating a shelter for homeless people and drug abusers. In the 90's, the ruined area was turned into a dump for construction materials used to build surrounding buildings.

While working on the plan for Fragmentos, Doris Salcedo faced the issue of how to deal with the ruins of the old house. Two options were possible: completely excise the ruins or integrate the broken walls and what was left of the house into the monument plan. The latter was chosen as a planning practice consistent with the very idea of memory and its preservation. The ruins of the house added a peculiar and very powerful meaning to the counter monument itself: the ruins of a far past were connected to the more recent destructions of the civil war producing a never-ending feeling of trauma. The monument itself is a ruin, as it is the life of the victims and in turn that of the whole Colombia.

\section{The space of Fragmentos}

Beside the ruins, what does the counter monument consist of? The question has not an easy nor obvious answer: it is difficult to understand at a first sight what the monument is here and even where the monument is. When visitors reach its location, they firstly see the title Fragmentos written on an external wall close to the entrance door. 
Once crossed the door, there is a small courtyard including some of the old house's ruined walls, plants and a path leading to the entrance of a long corridor (Figure 1). The corridor is made on its right end side of glass windows opening on the ruins: from them the visitors can see the rest of the old house (Figure 2), that can be also accessed from here.

The corridor is empty, its floor is made of large roughly-worked, corrugated and non-uniform metal tiles (Figure 3).

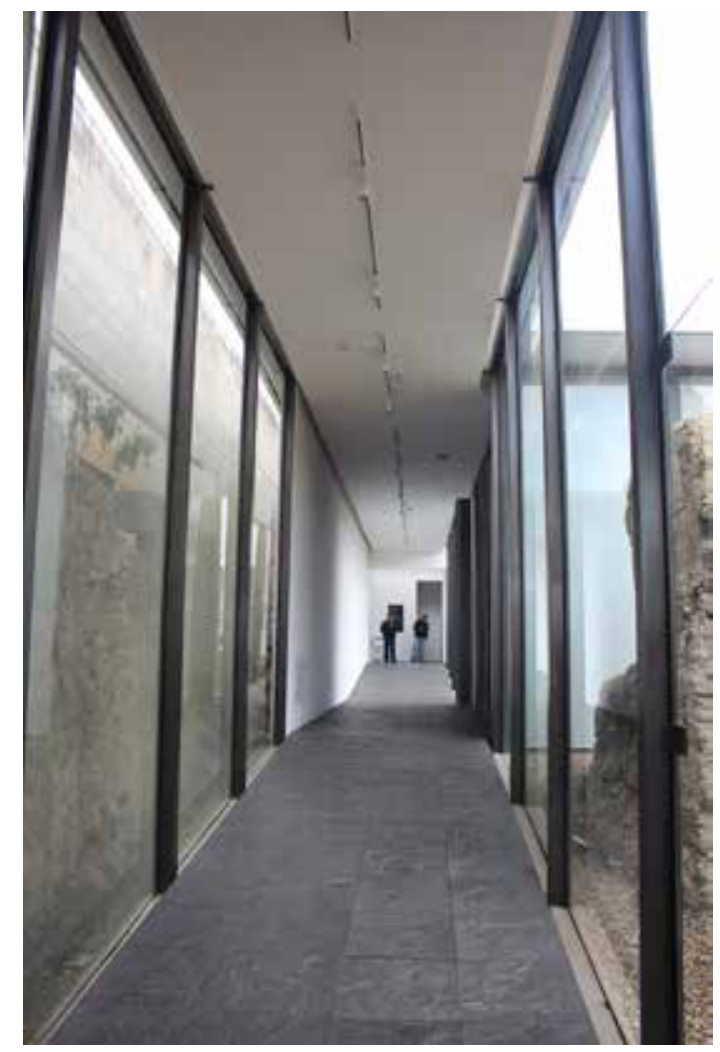

Figure 1: The main corridor of Fragmentos.

Fragmentos is organized around this long corridor that constitutes the spinal bone of the structure: it opens to three rooms, two of them used as exhibition spaces, and to the outside where the remains of the old house stood. Overall, the space is not immediately readable as a monument and the emotions of the visitors are encumbered by confusion as the visit goes on. The ruins play a major role, at least as a first impression: they interact with the corridor giving the misleading idea that the ruins themselves are the monument and the corridor is built to better admire the view on them. A tension is created between the old ruins and the modern space of the new corridor, installing a first isotopy of temporality.

The two rooms at the beginning and at the end of the main corridor are used for tempo- 
rary exhibitions. Temporary exhibitions - selected through public competition by an international committee - are open for six months; after that time the whole space is left empty for the following six months, before other exhibitions are open.

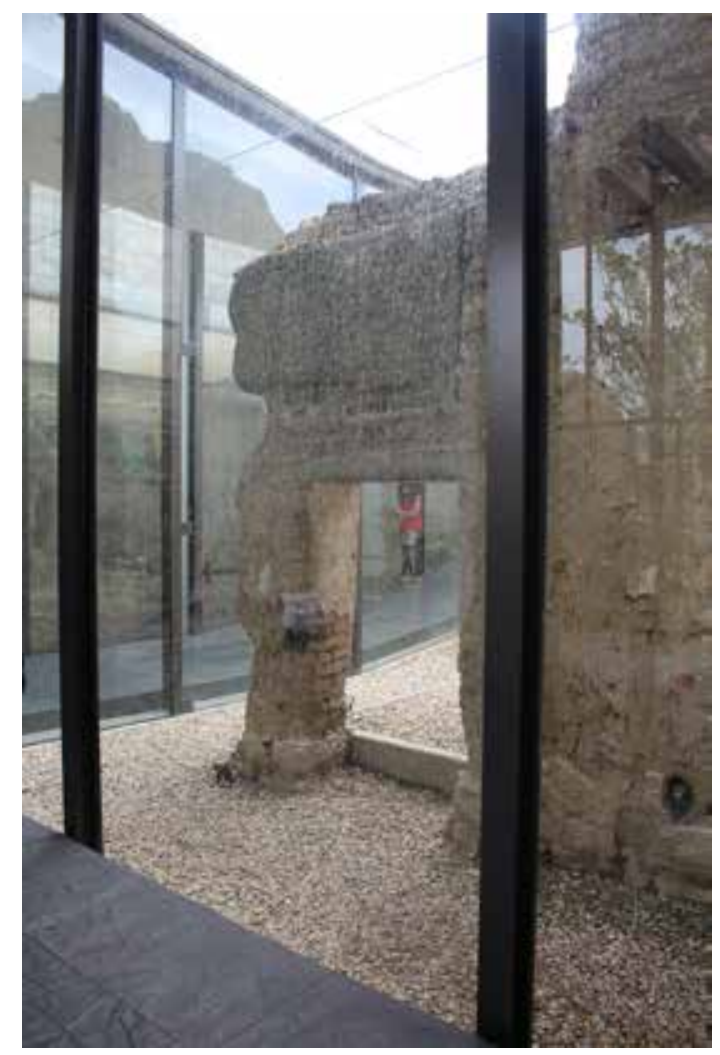

Figure 2: The ruins of the old house from the glass window.

When there are no temporary exhibitions, the whole space of the counter monument remains completely empty and the two empty rooms increase the feeling of uncertainty about what the monument is about and even where the monument is. Visitors will understand the original meaning of the counter monument only watching a long explanatory video made by Salcedo herself, broadcasted in a screen in the third room located in the middle of the corridor. The video explains the story of the monument, why it commemorates victims rather than peace and why it is to be considered a counter monument.

\section{Building Fragmentos}

Fragmentos was materially realized by the performative action of 17 women - whose names are written on a poster in the first exhibition room - victims of sexual violence and 
abuse from the various armed groups fighting the Colombian civil war. Salcedo melted the metal of 37 tons of weapons surrendered by the FARC and made metal thin sheets out of them. She then asked the 17 women to give form to the metal sheets using hammers: they did so for several days as to give voice to their anger and to express their feelings, signifying at the same time the symbolic end of the power relation imposed over them by the violence of weapons. As Salcedo explains in a poster at the site, this is the first time in history that a peace agreement allows victims of sexual violence to voice their pain and suffering through an action that aims to build a space commemorating the end of the conflict, taking an active part in its construction.

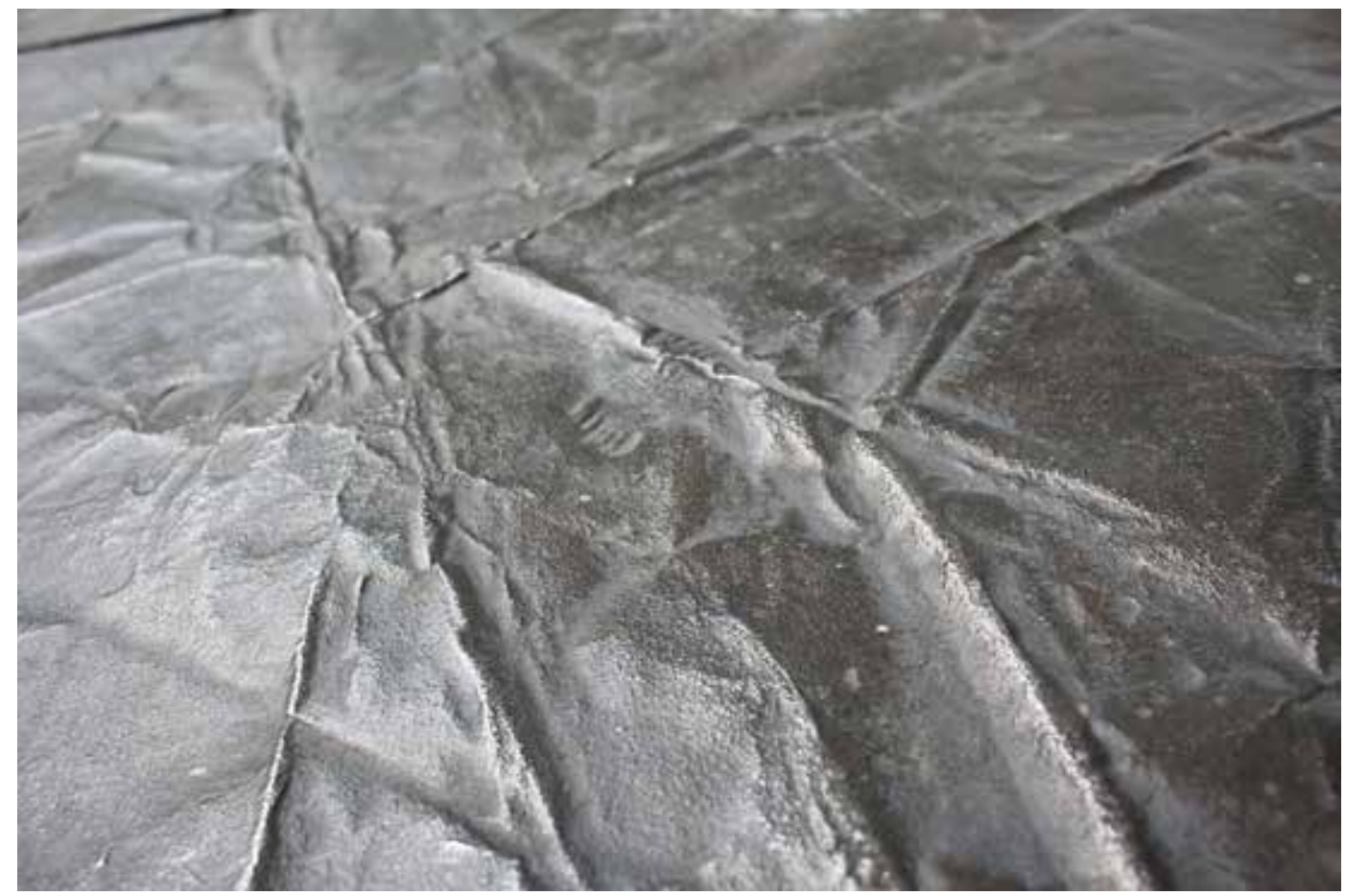

Figure 3: The floor of Fragmentos made of non-uniform metal tiles.

Only after watching the video, the visitors realize that the counter monument actually consists in the corrugated metal floor on which they were walking. Of course, there is more than this: in that floor the suffering and the anger of the women is objectivized and made concrete. We may say that in that floor feelings became matter. In each corrugation and fold of the iron can be seen the inflicted wound, the later suffering, the despair as well as the outburst of the reaction, the liberation of the victims' anger. Therefore, the floor is the material, visible result of a performative action which is at the same time a very complex narrative. 


\section{A narrative semiotic analysis of Fragmentos}

From the point of view of semiotic aspectuality, i.e. the point of view on the action, (Greimas and Courtés 1979: 12-16), Fragmentos is the terminative state of a performative action happened before. This action needs to be explained and understood to reconstruct the meaning of the counter monument. As the final phases of a complex narrative, the floor presupposes and activates, with its very presence, all the previous phases of the narrative: from sexual violence on women to their angry reaction and response.

Salcedo's work is a counter monument in many different ways. First because it is a counter narrative that opposes the classical, dominant narratives of war as well as of peace, that are too often part of official treaties and peace talks among politicians and government men. Fragmentos tells the visitor a different story that was rarely narrated before: a story of women victims, often marginalized in the dominant narratives of men that constitute the official historical narrative. It also does something more and more relevant: it activates a real transformation of women from objects to subjects, from a passive position to an active one. Through the performative action of hammering metal sheets women are no more passive victims but active creators of a work of art.

In the perspective of narrative semiotics, the transformation can be described both at the thematic and at the actantial level. The thematic role is changed from victim - somebody who is subject to an act of violence - to creator - somebody who is subject of an action. Beside the change of the thematic role, something very peculiar occurs at the level of actantial roles: if women as victims occupied the role of Object, now they acquire the role of Subject, as well as the one of Addresser with the power and the authority to sanction the story and establishing the overall value system (Greimas and Courtés 1979: 80-81, 226-227, 282, 333-335). As such, Fragmentos becomes a symbolic sanction of the whole Colombian civil war. A sanction that only women can pronounce and that it is made by using the very same material substance of the instruments of men's violence.

Fragmentos is a counter monument made to last in time. Differently from other counter monuments, it is not planned to disappear. Durability in time - one of the features that often counter monuments deconstruct - is not questioned here. Rather, its visibility is a trickier issue: Fragmentos is visible, but at the same time it consciously plays with a certain level of invisibility. Who among visitors would think that the monument is the metal floor on which they are walking? What is immediately visible - the ruins - is not the core component of the counter monument. The content of the counter monument is grasped in the process of visiting it and specifically after being informed by the video. Its meaning is thus resulting from a progressive discovery, rather than from a punctual encounter that can be caught without knowing the full story that lies behind. Fragmentos is thus not recognizable as a monument, rather than not visible as such. 
Fragmentos is a highly abstract and conceptual work, without any mimetic or figurative form of representation. Nothing is openly said about war and violence. Its main rhetorical device consists in a deep overturning of the form and function of weapons, the matter of which the counter monument is made of: weapons stop being instruments of death to become an anonymous and insignificant surface to walk on, something the visitor do not immediately pay attention to. The implicit vertical erectility of weapons is finally transformed in the flat horizontality of the floor.

\section{The monumentality of Fragmentos}

There is a last final question: is Fragmentos a real (counter) monument or it should be considered as a work of art, an installation, part of a larger museum structure? From an institutional point of view, it belongs to the National Heritage, it is managed by the National Museum of Colombia as part of the Culture Minister, and it is connected to a net of various museums in Bogotá.

However, to wonder about the real nature of Fragmentos - monument or work of art does not seem to be the right question to ask. A semiotically oriented approach would be to consider what are the spatial thresholds of this counter monument and which relations are established with its spatial environment.

Typically, a monument does not have an entrance: it is located in an open space, often a square, totally open to sight. This is not the case of Fragmentos: visitors have to go and visit it as it was a museum or an art gallery. This implies a quite different form of visiting practice. First, it has to be endowed with a specific intentionality of action: Fragmentos is not just there, as for example the statue of Simon Bolivar in the nearby Bolivar Square. One has to decide to see it, to look for its location and to enter a gate. None of these actions is casual, as it is the case in walking through a public space where a monument is located. The difference is also underlined by the presence of guides at the entrance, that mark a precise threshold between its inside and outside, and guardians inside it. Even from this perspective Fragmentos is a very peculiar: its relevance, beside its architectural beauty and originality, relies in its political message: the reversal of weapon in a floor to be step on, one of the humblest functions a monument has ever had.

\section{REFERENCES}

Alape, Arturo 1983. El bogotazo. Memorias del Olvido. Bogotá: Editorial Pluma y Lerner.

Gonzalo Sánchez G. 1983. Los días de la Revolución. Gaitanismo y 9 de abril en provincia, Bogotá: Centro Cultural Jorge Eliécer Gaitán. 
Greimas, Algirdas J. and Courtés, Joseph 1979. Sémiotique. Dictionnaire raisonné de la théorie du langage. Paris: Hachette [Semiotica. Dizionario ragionato della teoria del linguaggio. Milano: Mondadori, 2007).

Macdonald, Sharon 2009. Difficult heritage. Negotiating the Nazi past in Nuremberg and beyond. London: Routledge.

Panico, Mario 2018. II significato fluttuante dei monumenti. Il caso del monumento bulgaro all'Armata Rossa tra pratiche quotidiane e afflati nostalgici. VS 2018 (1): 107-124.

Violi, Patrizia 2019. Les monuments ont-ils encore un sens? Stratégies de contre et d'anti monumentalisation. In: Anne Beyaert-Geslin, Ludovic Chatenet and Françoise Okala (eds) Monuments, (dé)monumentalisation: Approches sémiotiques. Limoges: PUL.

Young James, 1992. The counter-monument: Memory against itself in Germany today. Critical Inquiry 18(2): 267-296.

Patrizia Violi is Professor of Semiotics at the University of Bologna, Department of Philosophy and Communication. She is the Director of the International Centre for the Humanities Umberto Eco and the Director of TRAME, Interdisciplinary Centre for the Study of Memory and Cultural Traumas, University of Bologna, Italy.

Email: patrizia.violi@unibo.it 